\title{
Hereditary Vitamin D Resistant Rickets Caused by a Novel Mutation in the Vitamin D Receptor That Results in Decreased Affinity for Hormone and Cellular Hyporesponsiveness
}

\author{
Peter J. Malloy, ${ }^{\star}$ T. Ross Eccleshall, ${ }^{\star}$ Coleman Gross, ${ }^{\star}$ Lionel Van Maldergem, ${ }^{\ddagger}$ Roger Bouillon, ${ }^{\S}$ and David Feldman ${ }^{\star}$ \\ *Stanford University, Stanford, California 94305; ${ }^{\ddagger}$ Institut de Pathologie et de Genétique, 6280 Loverval, Belgium; and ${ }^{\S}$ Katholieke \\ University, B-3000 Leuven, Belgium
}

\begin{abstract}
Mutations in the vitamin $\mathrm{D}$ receptor (VDR) result in target organ resistance to $1 \alpha, 25$-dihydroxyvitamin $\mathrm{D}\left[1,25(\mathrm{OH})_{2} \mathrm{D}_{3}\right]$, the active form of vitamin $D$, and cause hereditary 1,25 dihydroxyvitamin D resistant rickets (HVDRR). We analyzed the VDR of a patient who exhibited three genetic diseases: HVDRR, congenital total lipodystrophy, and persistent müllerian duct syndrome. The patient was treated with extremely high dose calcitriol $(12.5 \mu \mathrm{g} / \mathrm{d})$ which normalized serum calcium and improved his rickets. Analysis of $\left[{ }^{3} \mathrm{H}\right] 1,25(\mathrm{OH})_{2} \mathrm{D}_{3}$ binding in the patient's cultured fibroblasts showed normal abundance of VDR with only a slight decrease in binding affinity compared to normal fibroblasts when measured at $0^{\circ} \mathrm{C}$. The patient's fibroblasts demonstrated $1,25(\mathrm{OH})_{2} \mathrm{D}_{3}$-induction of 24-hydroxylase mRNA, but the effective dose was approximately fivefold higher than in control cells. Sequence analysis of the patient's VDR gene uncovered a single point mutation, H305Q. The recreated mutant VDR was transfected into COS-7 cells where it was 5 to 10 -fold less responsive to $1,25(\mathrm{OH})_{2} \mathrm{D}_{3}$ in gene transactivation. The mutant VDR had an eightfold lower affinity for $\left[{ }^{3} \mathrm{H}\right] 1,25(\mathrm{OH})_{2} \mathrm{D}_{3}$ than the normal VDR when measured at $24^{\circ} \mathrm{C}$. RFLP demonstrated that the patient was homozygous for the mutation while the parents were heterozygous. In conclusion, we describe a new ligand binding domain mutation in the VDR that causes HVDRR due to decreased affinity for $1,25(\mathrm{OH})_{2} \mathrm{D}_{3}$ which can be effectively treated with extremely high doses of hormone. (J. Clin. Invest. 1997. 99:297-304.) Key words: receptors • calcitriol • steroid • vitamin D-dependent rickets, type II • 1,25-dihydroxyvitamin D
\end{abstract}

\section{Introduction}

Vitamin D is essential for promoting calcium transport across the small intestine and for the normal development of bone. The hormonally active form of vitamin $\mathrm{D}, 1 \alpha, 25$-dihydroxyvi-

Address correspondence to David Feldman, M.D., Stanford University School of Medicine, Division of Endocrinology, Gerontology and Metabolism, Stanford University Medical Center, Room S005, Stanford, CA 94305-5103. Phone: 415-725-2910; FAX: 415-725-7085; E-mail: Feldman@cmgm.Stanford.edu

Received for publication 8 July 1996 and accepted in revised form 19 November 1996.

J. Clin. Invest.

(C) The American Society for Clinical Investigation, Inc.

0021-9738/97/01/297/08 \$2.00

Volume 99, Number 2, January 1997, 297-304 tamin $\mathrm{D}_{3}\left[1,25(\mathrm{OH})_{2} \mathrm{D}_{3}\right]$ mediates these biological actions by binding to the vitamin D receptor (VDR), ${ }^{1}$ a nuclear transcription factor that regulates gene expression. Hereditary 1,25dihydroxyvitamin D resistant rickets (HVDRR), also known as vitamin D-dependent rickets, type II, is an autosomal recessive disorder that has been shown to be caused by mutations in the $\operatorname{VDR}(1,2)$. The disease is characterized by early onset rickets, hypocalcemia, secondary hyperparathyroidism, elevated $1,25(\mathrm{OH})_{2} \mathrm{D}_{3}$ levels, and resistance to $1,25(\mathrm{OH})_{2} \mathrm{D}_{3}$ treatment $(3,4)$. Earlier research assaying $\left[{ }^{3} \mathrm{H}\right] 1,25(\mathrm{OH})_{2} \mathrm{D}_{3}$ binding in skin fibroblasts from affected individuals demonstrated two types of binding defects. In some cases fibroblasts were devoid of $\left[{ }^{3} \mathrm{H}\right] 1,25(\mathrm{OH})_{2} \mathrm{D}_{3}$ binding (so-called receptor negative phenotype) and in other cases fibroblasts had normal $\left[{ }^{3} \mathrm{H}\right] 1,25(\mathrm{OH})_{2} \mathrm{D}_{3}$ binding (so-called receptor positive phenotype) (1-18). In the receptor positive cases the VDR was shown to exhibit a decreased binding affinity for DNA. The cloning and sequencing of the human VDR cDNA (19) has provided the basis to elucidate the molecular abnormalities in affected individuals. The identification of the specific mutations in the gene encoding the VDR (20-32) has demonstrated that heterogeneous genetic defects in the VDR cause HVDRR.

The VDR is a member of the steroid/thyroid/retinoid receptor gene superfamily of transcription factors and shares a common structural and functional organization with the members of the thyroid/retinoid subgroup of receptors that includes the retinoic acid receptor (RAR), the retinoid $\mathrm{x}$ receptor (RXR), and the thyroid receptor (TR) $(33,34)$. The structural organization of VDR includes a highly conserved aminoterminal DNA-binding domain (DBD) and a carboxy-terminal ligand-binding domain (LBD). In addition, the VDR must form a complex with RXR in order to transactivate $1,25(\mathrm{OH})_{2} \mathrm{D}_{3}$ responsive genes via vitamin $\mathrm{D}$ response elements (VDREs) although recent evidence suggests that other co-activating factors are also involved. The heterodimerization of VDR with RXR is thought to occur via a region of the LBD that contains a 9-heptad repeat, a common structural motif found in this subfamily of nuclear hormone receptors (35).

To date, a total of 13 mutations causing HVDRR have been characterized (20-26, 28-32). The HVDRR syndrome is inherited as a recessive trait that requires two mutant VDR alleles in order to be expressed. Heterozygotic individuals appear to be phenotypically normal. Most of the mutations have been found in the DBD, a location that does not affect the

1. Abbreviations used in this paper: EMSA, electrophoretic mobility shift assay; HVDRR, hereditary 1,25-dihydroxyvitamin D resistant rickets; LBD, ligand-binding domain; DBD, DNA-binding domain; OP, osteopontin; RXR, retinoid $\mathrm{x}$ receptor; TR, thyroid receptor; VDR, vitamin D receptor; VDRE, vitamin D response element. 
ligand-binding properties of the receptor and hence were referred to earlier as the receptor positive phenotype. These mutations cause changes that interfere with the high affinity binding of the VDR to DNA, although the exact mechanism has not yet been elucidated. When these defective receptors are co-expressed in CV-1 or COS-7 cells along with a VDREreporter plasmid, the mutant receptors are unable to activate the transcription of the reporter gene even in the presence of very high concentrations of hormone $(23,25,29,30,32,36)$. On the other hand, only four mutations have been identified in the $\operatorname{LBD}(21,22,26,28,30)$. Two of these mutations, identified in individuals with the receptor negative phenotype, were stop mutations which resulted in the premature termination of the protein coding sequence and deletion of portions of the LBD $(21,22,28,30)$. One of these stop mutations was shown to have a secondary affect on VDR transcription and/or message stability that resulted in absent or diminished mRNA (22). The first missense mutation identified in the LBD, R271L, was found in a patient who was unresponsive to vitamin $\mathrm{D}_{3}$ therapy (28). Cultured fibroblasts from the patient failed to induce 25 hydroxyvitamin D-24-hydroxylase (24-hydroxylase) when exposed to as much as $1 \mu \mathrm{M} 1,25(\mathrm{OH})_{2} \mathrm{D}_{3}$. Interestingly, when this mutation was recreated and expressed in CV-1 cells, the mutant receptor was capable of transcriptional activation. However, the mutant receptor required 1,000-fold more hormone than the normal receptor in order to respond in these assays (28). The authors speculated that this mutation decreased the affinity of the receptor for $1,25(\mathrm{OH})_{2} \mathrm{D}_{3}$ by a factor of 1,000 although the ligand binding data were not presented. A C190Y mutation has also been identified in the VDR of a patient with HVDRR; however, details concerning hormone binding or functional properties of the mutant receptor were not described (26).

In this report, we update our recent findings on a child with HVDRR (37). We now describe the presence of a novel mutation $(\mathrm{H} 305 \mathrm{Q})$ in the VDR gene that results in a modest decrease in the affinity of the receptor for $1,25(\mathrm{OH})_{2} \mathrm{D}_{3}$ when measured at $0^{\circ} \mathrm{C}$ (approximately twofold) and a substantial decrease when measured at $24^{\circ} \mathrm{C}$ (approximately eightfold). The mutation leads to cellular resistance and decreased responsiveness to hormone. This type of mutation is unique in that it marks the first time that a patient with HVDRR has shown clinical improvement when treated with very high doses of $1,25(\mathrm{OH})_{2} \mathrm{D}_{3}$ which overcome the affinity defect and render the patient's cells responsive to hormone. The case is also unique in that the child has three rare recessive genetic diseases.

\section{Methods}

Culture conditions. Human skin fibroblasts and COS-7 cells were incubated at $37^{\circ} \mathrm{C}$ under a $5 \% \mathrm{CO}_{2}$ atmosphere in Dulbecco's modified Eagle's medium containing $10 \%$ FBS and appropriate antibiotics.

$\left[{ }^{3} \mathrm{H}\right] 1,25(\mathrm{OH})_{2} \mathrm{D}_{3}$ receptor binding assay. $\left[{ }^{3} \mathrm{H}\right] 1,25(\mathrm{OH})_{2} \mathrm{D}_{3}$ binding was assayed by incubating cytosol with radiolabeled ligand in the absence or presence of a 250 -fold excess of radioinert $1,25(\mathrm{OH})_{2} \mathrm{D}_{3}$ as previously described in reference 17 . Hydroxylapatite was used to separate bound and free hormone. Protein concentration was determined according to Bradford's method (38).

Northern blot analyses. Fibroblasts were grown to confluence and then treated with $1,25(\mathrm{OH})_{2} \mathrm{D}_{3}$ for $6 \mathrm{~h}$ in media containing $1 \%$ FBS. RNA was prepared as described in reference 22 . Total RNA (5 $\mu \mathrm{g})$ was electrophoresed on $1 \%$ agarose gels and then transferred to nylon filters. RNA was immobilized on the filter by ultraviolet irradiation. The filter was then hybridized with the 24-hydroxylase and L7 ribosomal RNA probes labeled by the random primer method as described in reference 39. $\mathrm{L} 7$ has been shown in multiple experiments to be unaffected by $1,25(\mathrm{OH})_{2} \mathrm{D}_{3}$ treatment and therefore can serve as a control for loading and transfer.

PCR and DNA sequencing. Exons seven and eight were amplified from genomic DNA using the oligonucleotide primers and PCR conditions as described in reference 22 except that the amplification steps were reduced to $30 \mathrm{~s}$ each. The PCR product was cloned and sequenced using $\left[\alpha^{35} \mathrm{~S}\right] \mathrm{dATP}$ and Sequenase Version 2.0 DNA sequencing kit (Amersham Corp., Arlington Heights, IL). The amino acid numbering system used in this paper is consistent with that previously described by Baker et al (19).

AlwNI RFLP. The PCR amplified products were digested with the restriction enzyme AlwNI at $37^{\circ} \mathrm{C}$ in the buffer supplied by the manufacturer (New England Biolabs Inc., Beverly, MA). Digestion products were resolved on $6 \%$ polyacrylamide gels and visualized by silver staining (Bio-Rad Laboratories, Richmond, CA) (22).

Site-directed mutagenesis and construction of VDR expression vectors. Site-directed mutagenesis of the wild-type VDR cDNA was done using the pALTER system (Promega Corp., Madison, WI) as described in reference 32 . The mutagenic oligonucleotide used was 5'-AAGCCGGACAGAGCCTGGAGC (the mutated base is underlined). Plasmid DNA was isolated and sequenced to confirm the presence of the desired point mutation in the VDR cDNA. The mutated VDR cDNA was then subcloned into the mammalian expression vector pEUK-C1 (Clontech, Palo Alto, CA) (32).

$V D R, V D R E-C A T$ cotransfection assay. COS-7 cells, in $60 \mathrm{~mm}$ plates, were transfected with plasmid DNA using LipofectAMINE (Gibco BRL, Gaithersburg, MD) as described in reference 32. A chloramphenicol acetyltransferase (CAT) ELISA (Boehringer Mannheim Biochemicals, Indianapolis, IN) was used to determine the amount of CAT protein produced in the assay (32). $\beta$-galactosidase activity was determined as described in reference 32 .

In vitro production of normal and mutant VDR. The normal and H305Q mutant VDR cDNAs cloned in pBluescript KSII (Stratagene, San Diego, CA) were amplified by PCR using primers: 5'GGGATCCATGGAGGCAATGGCGGCCAGCACTTCCCTGCCT and 5'-GAGGTCGACTAGTCAGGAGATCTCATT. The PCR products were digested with BamHI and XhoI and cloned into pCITE 3A (Novagen, Inc., Madison, WI). The normal and mutant proteins were produced by coupled in vitro transcription and translation of the VDR cDNA templates using the Single Tube Protein System 2 along with T7 RNA polymerase according to the manufacturer's instructions (Novagen, Inc.).

Electrophoretic mobility shift assay (EMSA). Cell extracts of Saccharomyces cerevisiae CB023 expressing the human RXR $\alpha$ cDNA via the yeast expression vector pG5 (40) was used as the source of $\mathrm{RXR} \alpha$. For EMSA, $5 \mu \mathrm{l}$ of in vitro translated VDR or $10 \mathrm{ng}$ of partially purified VDR (Panvera Corp., Madison, WI) was first incubated at ambient temperature for $30 \mathrm{~min}$ with $10 \mu \mathrm{g}$ yeast extract containing RXR $\alpha$ in $20 \mathrm{mM}$ Tris, $\mathrm{pH} 7.9,1 \mathrm{mM}$ EDTA, $100 \mathrm{mM}$ $\mathrm{NaCl}, 10 \%$ glycerol, $0.1 \% \mathrm{NP}-40,1 \mathrm{mM}$ DTT, $50 \mu \mathrm{g} / \mathrm{ml}$ poly dI-dC in the presence of $1-10 \mathrm{nM} 1,25(\mathrm{OH})_{2} \mathrm{D}_{3}$ or ethanol vehicle control. After the initial incubation, complementary annealed oligonucleotides corresponding to the human osteopontin VDRE (OP-VDRE) nucleotide sequence (5'-CCTGTAAAGGGTCGTATGGTTCATCTCA) (41) were added and the incubation continued for an additional 20 min. Before annealing one of the oligonucleotides was labeled using $\left[\gamma^{-}{ }^{32} \mathrm{P}\right]$-ATP $(3,000 \mathrm{Ci} / \mathrm{mmol}$, Amersham Corp. $)$ and T4 polynucleotide kinase (New England Biolabs Inc.). The final volume of the binding reaction was $30 \mu \mathrm{l}$. In some samples the VDR mAb, 9A7 $\gamma$, was added prior to the addition of labeled OP-VDRE or a 200 -fold excess of unlabeled OP-VDRE was added. In other control samples, in vitro translated $\beta$-galactosidase or partially purified VDR (PanVera Corp.) was substituted for in vitro translated VDR. For EMSA, $20 \mu \mathrm{l}$ of the binding mixture was applied to a $6 \%$ polyacrylamide gel 


\begin{tabular}{|c|c|c|c|c|}
\hline & Patient & Sister & Mother & Father \\
\hline Phenotype & HVDRR & HVDRR & Normal & Normal \\
\hline Genotype & Homozygous & Homozygous & Heterozygous & Heterozygous \\
\hline Treatment & Rocaltrol $12.5 \mu \mathrm{g} / \mathrm{d}$ & Dedrogyl $150 \mu \mathrm{g} / \mathrm{d}$ & - & - \\
\hline \multicolumn{5}{|l|}{ Serum concentrations* } \\
\hline Calcium $(8.5-10.4 \mathrm{mg} / \mathrm{dl})$ & 8.6 & 9.8 & 10.2 & 10.1 \\
\hline $25(\mathrm{OH})_{2} \mathrm{D}_{3}(7-60 \mathrm{ng} / \mathrm{ml})$ & $<2.5$ & 38 & 8 & 13 \\
\hline $1,25(\mathrm{OH})_{2} \mathrm{D}_{3}(20-80 \mathrm{pg} / \mathrm{ml})$ & 1,491 & 2,021 & 120 & 110 \\
\hline PTH $(3-40 \mathrm{pg} / \mathrm{ml})$ & 20 & 36 & 12 & 9 \\
\hline Osteocalcin $(11-43 \mathrm{ng} / \mathrm{ml})$ & 35 & 51 & 31 & 37 \\
\hline
\end{tabular}

* Normal ranges are given in parentheses.

and electrophoresed for $90 \mathrm{~min}$ at $85 \mathrm{~V}$ at ambient temperature in $0.5 \times$ Tris-borate EDTA buffer system $(1 \times=0.045 \mathrm{M}$ Tris borate, $0.001 \mathrm{M}$ EDTA). After electrophoresis, the gel was dried onto filter paper and exposed to Hyperfilm (Amersham Corp.) at $-70^{\circ} \mathrm{C}$ before development.

\section{Results}

Case report. The patient described in this report, a Turkish boy born to first cousins, initially presented at two years of age with rickets and subsequently was diagnosed with HVDRR. As recently described by Van Maldergem et al. (37), the boy has three rare genetic diseases: HVDRR, total lipodystrophy, and persistent müllerian duct syndrome. In brief, the child exhibited the classical features of HVDRR, including severe rickets, hypocalcemia, hypophosphatemia, secondary hyperparathyroidism, and elevated circulating $1,25(\mathrm{OH})_{2} \mathrm{D}_{3}$ levels. Interestingly, he was unresponsive to a one month treatment regimen with cholecalciferol $(4,800 \mathrm{IU} / \mathrm{d})$ followed by a trial with conventional doses of Rocaltrol (37).
Since the initial report, additional clinical data on this patient and other members of his immediate family have been obtained (Table I). The patient's sister also has been diagnosed with HVDRR. The patient is currently being treated with $12.5 \mu \mathrm{g}$ Rocaltrol per d, while his sister is being treated with $150 \mu \mathrm{g}$ of Dedrogyl [calcifidiol or $25(\mathrm{OH}) \mathrm{D}_{3}$ ] per $\mathrm{d}$. The children both have responded to these treatments with restoration of eucalcemia, suppression of elevated PTH and healing of rickets (Table I). The $25(\mathrm{OH}) \mathrm{D}_{3}$ serum values of the patient and sister generally reflect the particular treatment regimen that they were receiving, i.e., the $25(\mathrm{OH}) \mathrm{D}_{3}$ level in the patient on Rocaltrol went to $<2.5 \mathrm{ng} / \mathrm{ml}$ while the sister's $25(\mathrm{OH}) \mathrm{D}_{3}$ levels on Dedrogyl were normal $(38 \mathrm{ng} / \mathrm{ml})$. During treatment, the serum $1,25(\mathrm{OH})_{2} \mathrm{D}_{3}$ levels in each child have been maintained at concentrations 20 - to 25 -fold above the normal range. Since this therapy has only normalized the serum calcium, the lack of hypercalcemia in the presence of serum concentrations of $1,25(\mathrm{OH})_{2} \mathrm{D}_{3}$ greater than $1,000 \mathrm{pg} / \mathrm{ml}$, clearly demonstrated severe resistance to the action of the hormone (Table I).
A

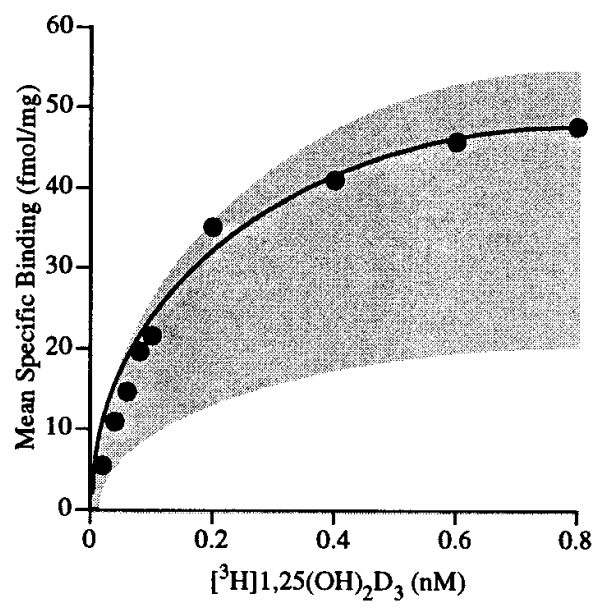

B

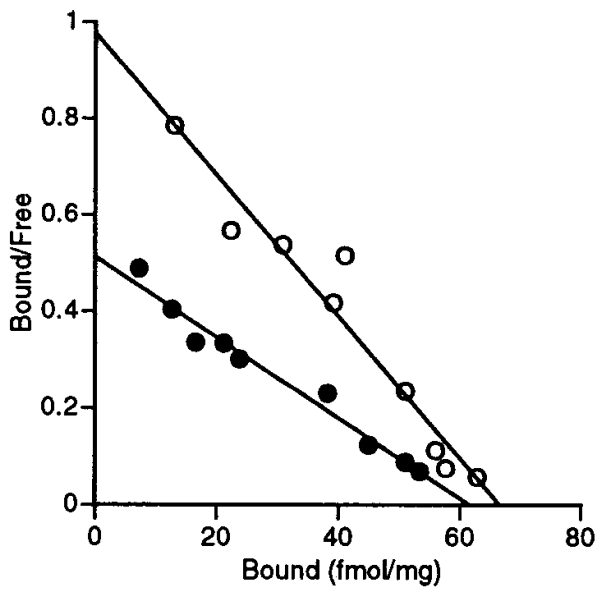

Figure 1. Saturation analysis and Scatchard plot of specific $\left[{ }^{3} \mathrm{H}\right] 1,25(\mathrm{OH})_{2} \mathrm{D}_{3}$ binding in the patient's fibroblasts. Cytosol from fibroblasts of the patient and normal controls were incubated at $0^{\circ} \mathrm{C}$ with $\left[{ }^{3} \mathrm{H}\right] 1,25(\mathrm{OH})_{2} \mathrm{D}_{3}$ and then the bound and free hormone were separated by HAP. ( $A$ ) Saturation plot of specific $\left[{ }^{3} \mathrm{H}\right] 1,25(\mathrm{OH})_{2} \mathrm{D}_{3}$ binding (shaded area represents the normal range from multiple previous experiments performed in our laboratory); (B) Scatchard plot of the binding data from a representative experiment. Symbols are index case (๑), and a concurrently assayed normal $(\bigcirc)$. 


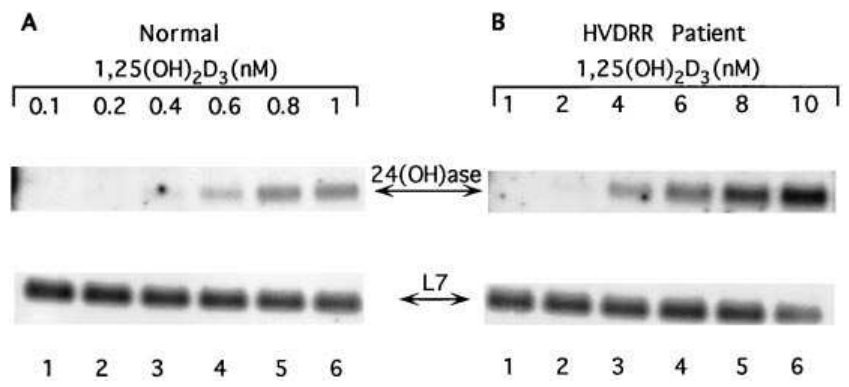

Figure 2. Northern blot analyses of the expression of the 24-hydroxylase mRNA in normal fibroblasts and fibroblasts from the index case with HVDRR. Fibroblasts were treated with the indicated dose of $1,25(\mathrm{OH})_{2} \mathrm{D}_{3}$ for $6 \mathrm{~h}$ in media containing $1 \% \mathrm{FBS}$ and then RNA was isolated. Northern blots were prepared and then hybridized with labeled 24-hydroxylase and $\mathrm{L} 7$ ribosomal protein cDNA probes. The concentration of $1,25(\mathrm{OH})_{2} \mathrm{D}_{3}$ is shown above the blot. $(A)$ Normal control; $(B)$ index case. Expression of the L7 ribosomal protein mRNA served as a control. Lane numbers are at the bottom.

$\left[{ }^{3} \mathrm{H}\right] 1,25(\mathrm{OH})_{2} \mathrm{D}_{3}$-binding. Studies were conducted in fibroblasts cultured from family members to determine whether the cause of the HVDRR in this family was due to a mutation in the VDR. As depicted in Fig. 1, the cultured fibroblasts from the index case showed a normal complement of VDR (60 $\mathrm{fmol} / \mathrm{mg}$ protein) as determined by $\left[{ }^{3} \mathrm{H}\right] 1,25(\mathrm{OH})_{2} \mathrm{D}_{3}$ binding assays. The values are at the high end of a range of five normal fibroblasts assayed in our laboratory. However, as compared to VDR from normal fibroblasts, a slight (approximately twofold) decrease in the affinity of the receptor for $1,25(\mathrm{OH})_{2} \mathrm{D}_{3}$ was demonstrated $\left(\mathrm{K}_{\mathrm{d}} 2.3 \pm 1.3 \times 10^{-10} \mathrm{M}\right.$ for the patient, $n=3$, versus $\mathrm{K}_{\mathrm{d}} 0.52 \pm 0.18 \times 10^{-10} \mathrm{M}$ for the controls, $n=5$ ). This modest difference in binding affinity was independently shown in our previous study (37) and demonstrates the mild nature of this defect that could be detected by ligand binding when performed at $0^{\circ} \mathrm{C}$.

$1,25(\mathrm{OH})_{2} \mathrm{D}_{3}$ response. To ascertain whether the fibroblasts from the patient were responsive to $1,25(\mathrm{OH})_{2} \mathrm{D}_{3}$, the induction of 24-hydroxylase mRNA, a $1,25(\mathrm{OH})_{2} \mathrm{D}_{3}$-responsive gene, was assayed by northern blot following treatment of cells with a series of increasing concentrations of hormone $\left(0.1-10 \mathrm{nM} 1,25(\mathrm{OH})_{2} \mathrm{D}_{3}\right)$ for $6 \mathrm{~h}$. Exposure to $1,25(\mathrm{OH})_{2} \mathrm{D}_{3}$ for $6 \mathrm{~h}$ induces normal cells to synthesize the $2.4 \mathrm{~kb} 24$-hydrox- ylase mRNA (42). As shown in Fig. 2, in normal fibroblasts the 24-hydroxylase mRNA is undetectable at $0.1 \mathrm{nM} 1,25(\mathrm{OH})_{2} \mathrm{D}_{3}$ (Fig. 2, $A$, lane 1). However, when the concentration of the hormone is raised to $0.4 \mathrm{nM}$ and higher, the abundance of the transcript increases in a $1,25(\mathrm{OH})_{2} \mathrm{D}_{3}$ dose-dependent manner (Fig. 2, A, lanes 3-6). In contrast, the 24-hydroxylase mRNA was not detected in the fibroblasts from the patient when the cells were treated with $1 \mathrm{nM} 1,25(\mathrm{OH})_{2} \mathrm{D}_{3}$ (Fig. 2, $B$, lane 1). The 24-hydroxylase mRNA was detected when the concentration was raised to $4 \mathrm{nM} 1,25(\mathrm{OH})_{2} \mathrm{D}_{3}$ (Fig. 2, B, lane 3). The cells then responded to the increasing amounts of $1,25(\mathrm{OH})_{2} \mathrm{D}_{3}$ in a dose-dependent manner (Fig. 2, B, lane 3-6). A trace amount of 24-hydroxylase mRNA was detected in the $2 \mathrm{nM} 1,25(\mathrm{OH})_{2} \mathrm{D}_{3}$ lane when the blot was exposed for a longer time. These data demonstrate that the patient's fibroblasts are hyporesponsive to $1,25(\mathrm{OH})_{2} \mathrm{D}_{3}$ treatment. Approximately fivefold more hormone is required by the patient's fibroblasts to achieve the same level of response as normal fibroblasts. L7 mRNA levels served as control for loading. In other experiments, the affected sister was shown to have resistance to $1,25(\mathrm{OH})_{2} \mathrm{D}_{3}$ similar to the index case whereas the mother had a normal response (data not shown).

Nucleotide sequence analysis. Since the $1,25(\mathrm{OH})_{2} \mathrm{D}_{3}$ binding and functional response data indicated that the VDR from this patient was abnormal and northern blots demonstrated the VDR mRNA to be expressed normally and to be the correct size (data not shown), the nucleotide sequence of the VDR gene was examined for mutations in the exons encoding the VDR protein. The findings detailed above, suggesting a defect in the LBD, led us to focus on this region of the VDR. As shown in Fig. 3, a $\mathrm{C}$ to $\mathrm{G}$ missense mutation was identified in exon eight. This mutation replaces a histidine residue with a glutamine residue at position 305 (H305Q) in the VDR. Sequence analysis of the entire coding region of the VDR gene found no other mutations.

Family analyses by RFLP. To determine whether the sister, who also suffers from HVDRR, had the same mutation as the patient and whether other members of the family were carriers of this mutation, DNA samples from each available family member were obtained and analyzed for the mutation. Since the mutation generates an AlwN I restriction site, we developed an RFLP analysis to detect the mutation using this restriction endonuclease. PCR was used to amplify the region of DNA containing the mutation and these products were then
A

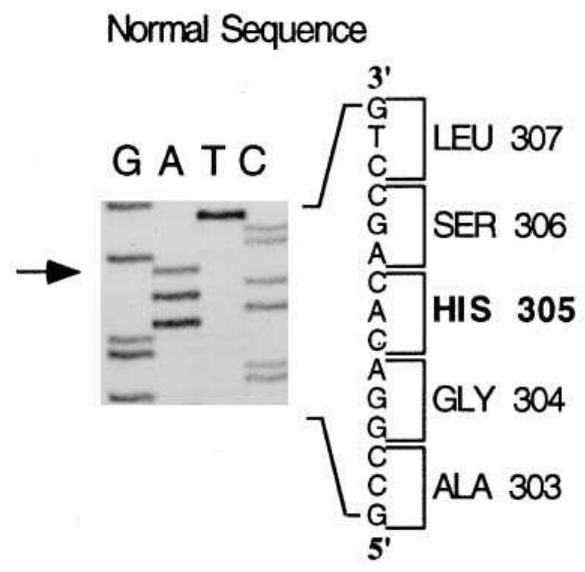

B

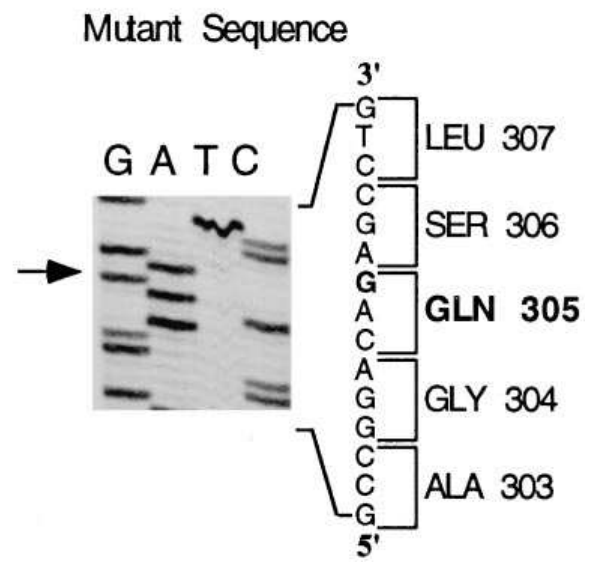

Figure 3. DNA sequence analysis of the VDR gene. Exon 8 DNA from the index case and normal fibroblasts was amplified by PCR and then sequenced. $(A)$ Nucleotide sequence of normal VDR; $(B)$ nucleotide sequence of the index case. The position of the single $\mathrm{C}$ to $\mathrm{G}$ missense mutation is indicated by the arrows and the altered amino acid in boldface type. 


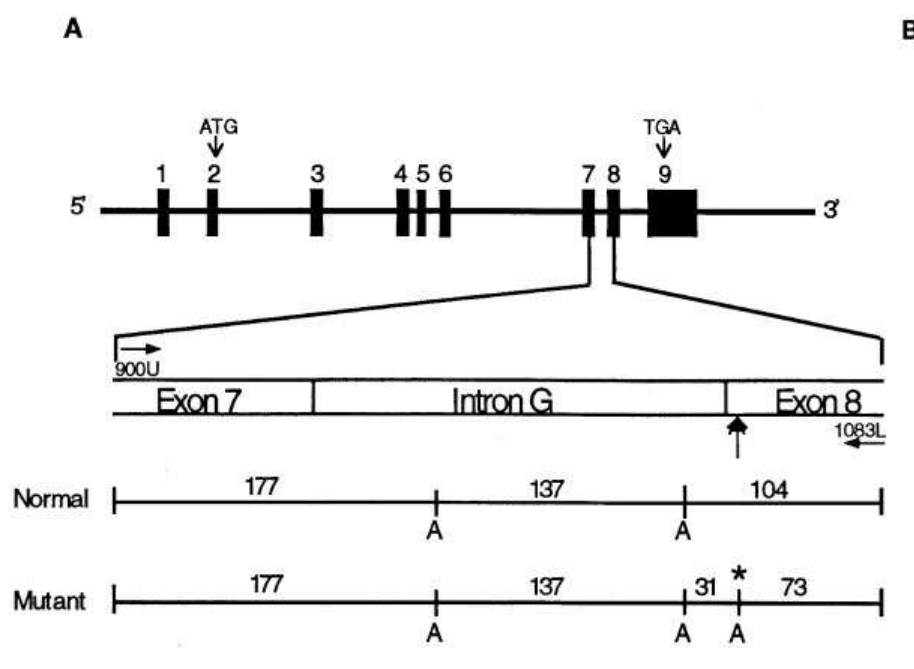

B
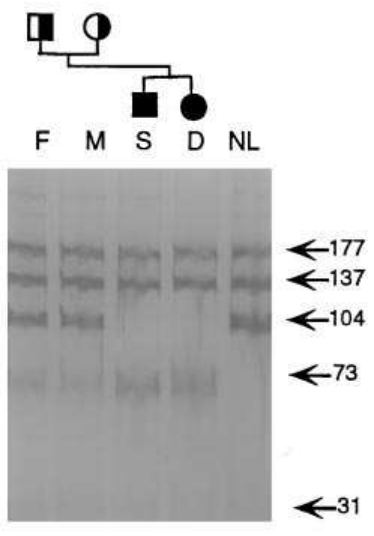

$\begin{array}{lllll}1 & 2 & 3 & 4 & 5\end{array}$
Figure 4. AlwN I RFLP. (A) Schematic representation of $A l w N$ I digestion showing amplification from genomic DNA by oligonucleotide primers $900 \mathrm{U}$ and $1083 \mathrm{~L}$ to generate a 418 bp fragment. The $A l w N$ I $(A)$ restriction sites for both normal (top) and mutant (bottom) alleles are shown. The site that is generated by the point mutation is indicated with an asterisk. (B) Polyacrylamide gel electrophoresis of PCR products after digestion with $A l w N$ I in the father $(F$, lane 1$)$, mother $(M$, lane 2), son (index case) with HVDRR ( $S$, lane 3$)$, daughter with HVDRR $(D)$, lane 4), and a normal control

$(N L$, lane 5). Fragment size (bp) is shown on the right. The $31 \mathrm{bp}$ band runs as a faint band at the bottom of the gel and is better detected on the gels then the photograph in all lanes but the $N L$.

digested with $A l w N$ I (Fig. 4, $A$ ). The restriction patterns generated from the digests were then analyzed by gel electrophoresis. As predicted from the restriction map (Fig. 4, A), a normal control exhibits three bands (177, 137 and 104 bps) due to two $A l w N$ I sites in the region (Fig. 4, $B$, lane 5). The patient and his affected sibling, exhibit four bands (177, 137, 73 and 31 but not 104 bps) (Fig. 4, B, lanes 3 and 4 ). This pattern is consistent with the presence of a third $A l w N$ I site created by the mutation in this region (Fig. 4, $A$ ), and confirms their homozygosity for the mutation. The parents exhibit all five bands (Fig. $4, B$, lanes 1 and 2) which demonstrates that they are heterozygous for the mutation and carriers of the mutant allele.

Having determined the nature of the mutation in the VDR gene and established the autosomal recessive inheritance of the defective gene, the mutation was reconstructed in the VDR cDNA by site directed mutagenesis. The effects of this single base change in the VDR on hormone binding, transactivation potential, and ability to complex with RXR and form a heterodimer on a VDRE were examined.

$\left[{ }^{3} \mathrm{H}\right] 1,25(\mathrm{OH})_{2} \mathrm{D}_{3}$-binding of recreated mutation. Scatchard analyses of $\left[{ }^{3} \mathrm{H}\right] 1,25(\mathrm{OH})_{2} \mathrm{D}_{3}$-binding in COS-7 cells transfected with normal and mutant VDR cDNAs showed that the mutant VDR had an average $K_{\mathrm{d}}$ of $1.2 \times 10^{-10} \mathrm{M}$ which was slighty lower affinity than the normal VDR which had a $K_{\mathrm{d}}$ of $0.9 \times 10^{-10} \mathrm{M}$ when assayed at $0^{\circ} \mathrm{C}(n=2)$. As shown in Fig. 5, when $\left[{ }^{3} \mathrm{H}\right]-1,25(\mathrm{OH})_{2} \mathrm{D}_{3}$ binding was performed at $24^{\circ} \mathrm{C}$, the normal VDR exhibited a $K_{\mathrm{d}}$ of $1.1 \pm 0.3 \times 10^{-10} \mathrm{M}$ which was similar to that observed at $0^{\circ} \mathrm{C}$. In contrast, the mutant VDR showed a $K_{\mathrm{d}}$ of $8.7 \pm 3.1 \times 10^{-10} \mathrm{M}$ at $24^{\circ} \mathrm{C}$, approximately eightfold lower than the $\mathrm{Kd}$ for the normal VDR assayed at $24^{\circ} \mathrm{C}(n=3)$.

Transactivation analysis of recreated mutation. Fig. 6 shows the results of transactivation experiments performed in COS-7 cells cotransfected with either the normal or mutant VDR cDNA expression vectors and a VDRE-CAT reporter plasmid. When the cells were transformed with the normal VDR cDNA, a $1,25(\mathrm{OH})_{2} \mathrm{D}_{3}$ dose-dependent $(0.5-100 \mathrm{nM})$ rise in CAT protein was observed. A 3-3.5-fold increase was achieved with a definite response detected at $0.5 \mathrm{nM}$ and a maximum re- sponse approached at $10 \mathrm{nM} 1,25(\mathrm{OH})_{2} \mathrm{D}_{3}$. A $1,25(\mathrm{OH})_{2} \mathrm{D}_{3}$ dose-dependent rise in CAT protein was also observed in the cells transformed with the mutant VDR cDNA. However, a 5-10 fold higher concentration of $1,25(\mathrm{OH})_{2} \mathrm{D}_{3}$ was required by the cells transformed with the mutant VDR to achieve the same effect observed in cells transformed with the normal gene. No response could be detected at $1 \mathrm{nM} 1,25(\mathrm{OH})_{2} \mathrm{D}_{3}$. Interestingly, with higher concentrations of $1,25(\mathrm{OH})_{2} \mathrm{D}_{3}$, the
A

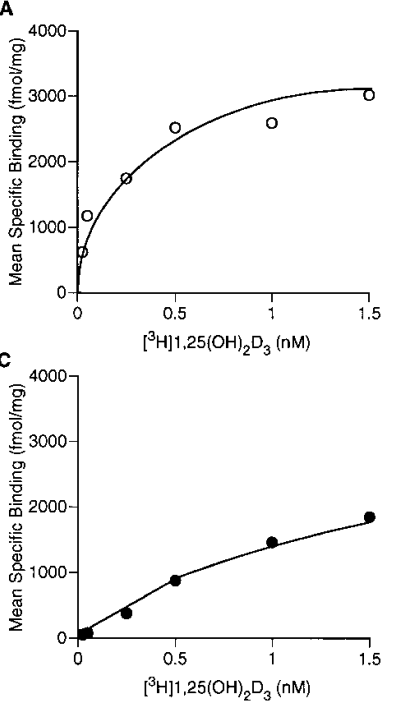

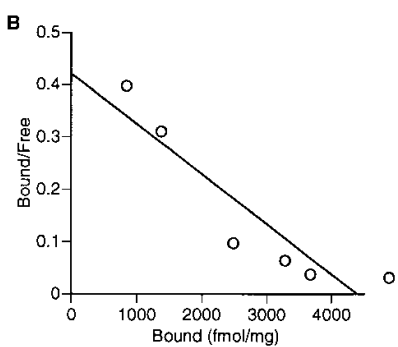

D

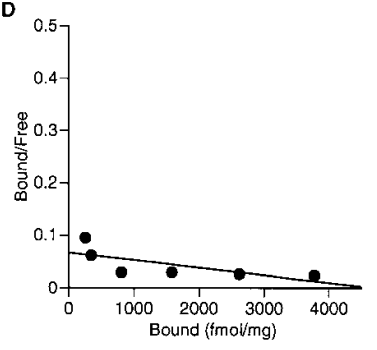

Figure 5. Saturation analysis and Scatchard plot of specific $\left[{ }^{3} \mathrm{H}\right] 1,25(\mathrm{OH})_{2} \mathrm{D}_{3}$ binding of normal and mutant VDR expressed in COS-7 cells. Cytosol from COS-7 cells were incubated at $24^{\circ} \mathrm{C}$ with $\left[{ }^{3} \mathrm{H}\right] 1,25(\mathrm{OH})_{2} \mathrm{D}_{3}$ and then the bound and free hormone were separated by HAP. ( $A$ ) Saturation plot of specific $\left[{ }^{3} \mathrm{H}\right] 1,25(\mathrm{OH})_{2} \mathrm{D}_{3}$ binding in the normal VDR; $(B)$ a representative Scatchard plot of the binding data from normal VDR; $(C)$ saturation plot of specific $\left[{ }^{3} \mathrm{H}\right] 1,25(\mathrm{OH})_{2} \mathrm{D}_{3}$ binding in the mutant VDR; $(D)$ a representative Scatchard plot of the binding data from mutant VDR. Symbols are mutant VDR $(\bullet)$, and normal VDR $(\bigcirc)$. 


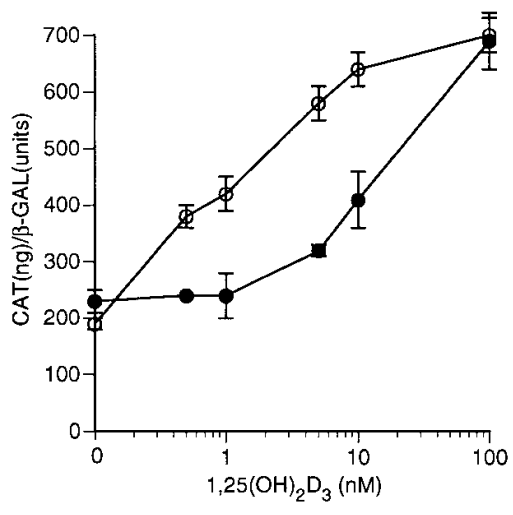

dent transactivation of the CAT gene. Symbols and H305Q mutant $(\bullet)$ receptors. The data represent the mean \pm SD of three experiments.

normal maximal CAT response could be achieved. These findings are consistent with the experiments performed in the patient's cultured fibroblasts which showed a diminished $1,25(\mathrm{OH})_{2} \mathrm{D}_{3}$ response in the induction of 24-hydroxylase gene expression which could be overcome at high concentrations of $1,25(\mathrm{OH})_{2} \mathrm{D}_{3}$. There are minor differences in the absolute concentration of $1,25(\mathrm{OH})_{2} \mathrm{D}_{3}$ that the cells respond to, probably reflecting differences between the fibroblast (endogenous genes) and the COS cell (transfected VDR-reporter gene) systems. Overall, the results clearly indicate that the H305Q mutation in the VDR imparts a binding affinity defect with cellular hyporesponsiveness to $1,25(\mathrm{OH})_{2} \mathrm{D}_{3}$ action that can be overcome at high doses of hormone.

Heterodimerization and VDRE-binding of mutant VDR. Since the location of the H305Q mutation resides in the area of the VDR that is near to and may be involved in heterodimer formation with RXR, the ability of the mutant receptor to heterodimerize with RXR and bind to the human osteopontin

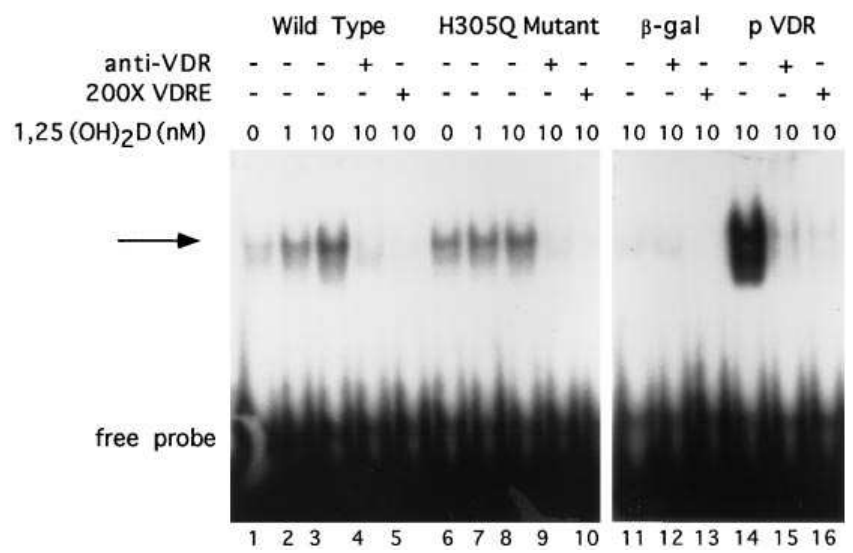

Figure 7. Heterodimerization and DNA-binding activity of H305Q mutant VDR. Normal and H305Q mutant VDR produced by in vitro translation were evaluated for RXR $\alpha$ heterodimer formation and DNA-binding activity by GMSA using $6 \%$ polyacrylamide gels as described in Methods. Radiolabeled OP-VDRE sequences were used in the incubation mixture. The VDR-RXR DNA-binding activity is highlighted by the arrow. In vitro produced $\beta$-galactosidase $(\beta$-gal $)$ and partially purified VDR $(p V D R)$ served as controls. Lane numbers are at the bottom.
(OP) VDRE was examined by GMSA. Following in vitro transcription of the normal VDR and H305Q mutant VDR cDNAs, the receptor proteins were produced by in vitro translation using reticulocyte lysates. As shown in Fig. 7, a band shift was observed with the wild type VDR and the intensity of the band shift increased as the amount of hormone increased (Fig. 7, lanes 1-3). The band shift was blocked by addition of antiVDR mAb or by addition of excess unlabeled OP-VDRE (Fig. 7, lanes 4 and 5). When the H305Q mutant VDR was tested, a normal band shift was observed which could also be blocked by the antibody or excess unlabeled probe (Fig. 7, lanes 6-10). In the absence of RXR, neither the wild type VDR nor the H305Q mutant VDR bound to the OP-VDRE (data not shown). No band shift was observed with the $\beta$-galactosidase control (Fig. 7, lanes 11-13) and a strong band shift was demonstrated using partially purified VDR which could be blocked by the anti-VDR mAb or by addition of excess unlabeled oligonucleotide (Fig. 7, lanes 14-16). These data suggest that the H305Q mutation does not interfere with RXR dimerization or binding to the OP-VDRE.

\section{Discussion}

In this study, we analyzed the biochemical and molecular properties of the VDR in a family with HVDRR. The index patient exhibited the classical features of the syndrome including early onset rickets, hypocalcemia, secondary hyperparathyroidism and elevated serum $1,25(\mathrm{OH})_{2} \mathrm{D}_{3}$ levels. The child did not have alopecia, a finding often associated with this disease (4-6, 9, 10, 12, 13, 16, 17, 27, 43-46). Unlike other patients who required intravenous calcium infusions to treat the symptoms of HVDRR because they failed to improve with $1,25(\mathrm{OH})_{2} \mathrm{D}_{3}$ therapy (46-49), the patient in this study responded to treatment with extremely high doses of Rocaltrol. During treatment, the patient's serum $1,25(\mathrm{OH})_{2} \mathrm{D}_{3}$ levels rose to extraordinarily high values $(>1,000 \mathrm{pg} / \mathrm{ml})$ which provided additional evidence of his resistant state. However, the treatment improved the rickets and restored the patient's calcium levels to normal. Similar results, including the healing of rickets, were observed in the patient's sister who is also affected with HVDRR.

Because of the clinical impression of HVDRR, fibroblasts cultures were established and used to determine whether the VDR from the child harbored a mutation. In cell extracts, $\left[{ }^{3} \mathrm{H}\right] 1,25(\mathrm{OH})_{2} \mathrm{D}_{3}$ binding was clearly detectable and the abundance of the receptor was in the high end of the normal range. However, a slight decrease in the affinity of the VDR for $1,25(\mathrm{OH})_{2} \mathrm{D}_{3}$ could be discerned. To ascertain whether the patient's fibroblasts were resistant to $1,25(\mathrm{OH})_{2} \mathrm{D}_{3}$, the induction of the 24-hydroxylase gene was assayed as a marker of $1,25(\mathrm{OH})_{2} \mathrm{D}_{3}$ responsiveness. Interestingly, the cells did respond to the hormone but the concentration required was approximately 5-10-fold higher than the amount of hormone needed by normal cells to achieve the same response. The cells were clearly resistant to $1 \mathrm{nM} 1,25(\mathrm{OH})_{2} \mathrm{D}_{3}$ while the normal cells were responsive to this concentration. The binding and cell response findings suggested that the defect in the VDR was likely to be in the LBD and not in the DBD. Also, most cases with alopecia have mutations in the DBD.

The LBD of the VDR is located in the carboxyl half of the protein and encompasses $\sim 300$ amino acids. The crystal structures of the LBDs of the related receptors TR (50), RAR (51), 
and RXR (52) have been determined and a common structural design for the LBD has emerged. The LBD consists of a hydrophobic core that is composed of 11-12 $\alpha$-helices (H1-H12) and two to four short $\beta$-sheets. Extrapolating from this crystallographic data to the VDR, the mutation H305Q identified in this study would be found within this hydrophobic core. The H305Q mutation would most likely occur in the loop connecting two $\alpha$-helices together (the loop connecting H6 to H7 in RXR and H7 to H8 in TR) and would appear to disrupt the normal contacts between the protein and the ligand or to destabilize the bound conformation. In either case, the net effect of the H305Q mutation could be envisioned to alter the binding affinity for ligand, thereby possibly decreasing the ability of the receptor to change to the active conformation. However, at higher hormone concentrations, we found that this affinity defect could be overcome and once fully occupied, the receptor can achieve full transcriptional activity.

A comparison of the amino acid sequences in the loop that connects the two $\alpha$-helices together among members of the thyroid/retinoid subgroup reveals that $\mathrm{H} 305$, which is found only in the VDR, aligns to a glycine which is highly conserved at this location among the other receptors. Interestingly, in TR this glycine has been the site of at least four different mutations which leads to generalized resistance to thyroid hormone (53). The TR mutations are inherited as autosomal dominant negatives since only one of the alleles has been mutated. A natural dominant negative mutation has not yet been described in the VDR and in most cases the heterozygotic parents have been reported to have a normal phenotype. In this family, the parents appear to display a very mild form of hormone resistance, since their serum $1,25(\mathrm{OH})_{2} \mathrm{D}_{3}$ levels are elevated above the normal range (Table I). The H305Q mutant receptor requires a higher hormone concentration to fulfill its role as a transactivator and maintain normal calcium homeostasis. We speculate that the mild hormone resistance in the heterozygous parents leads to increased production of $1,25(\mathrm{OH})_{2} \mathrm{D}_{3}$ as a consequence of feedback regulation.

Two additional facts about this case are of substantial interest and warrant discussion. First, the presence of three genetic diseases: HVDRR, total lipodystrophy, and persistent müllerian duct syndrome, affecting a single individual is highly unusual and extremely unlikely to occur by chance alone. However, at this time we can not explain this statistically remote event. We now know that the HVDRR is the result of a point mutation in the VDR gene, and since the sister has the same genetic defect present in the index case without the association of the other two diseases, we have tentatively concluded that the HVDRR syndrome is inherited independently of the other two genetic defects. However, we have not ruled out that there may be a common connection among the defects in the index case which may involve the VDR.

A second area that requires comment concerns the apparent discrepancy between the mild resistance observed in the patient's cultured fibroblasts with the level of resistance seen in both children. While receiving high dose vitamin $\mathrm{D}$ therapy, the $1,25(\mathrm{OH})_{2} \mathrm{D}_{3}$ serum levels were $\sim 25$-fold higher than normal indicating a substantial resistance to the hormone. Ligandbinding could only detect an approximately twofold difference in affinity between the mutant and normal receptors at $0^{\circ} \mathrm{C}$ but the affinity defect was more pronounced (approximately eightfold lower) when measured at elevated temperatures $\left(24^{\circ} \mathrm{C}\right)$. The difference in hormone responsiveness between the cul- tured mutant and normal fibroblasts (assayed at $37^{\circ} \mathrm{C}$ ) was $\sim 5$ to 10 -fold. However, these estimates (up to 10-fold) of resistance are distinctly less than the 25 -fold difference in circulating $1,25(\mathrm{OH})_{2} \mathrm{D}_{3}$ levels found in the serum of the two children. We can not explain this discrepancy at this time but other defects that only become manifest in the in vivo setting rather than in isolated cultured fibroblasts may be at play. It is possible, for instance, within a cell-specific context that other tissues might exhibit more resistance than dermal fibroblasts. Another possibility is that pharmacokinetic factors may make the hormone less available in vivo. Resolution of this discrepancy between cultured cells and the in vivo setting would no doubt add to our understanding of the $1,25(\mathrm{OH})_{2} \mathrm{D}_{3}$ action pathway.

The H305Q mutation reported here adds to the growing list of mutations found in the VDR and further defines the structural and functional organization of this protein. This mutation occurs in an amino acid that is not highly conserved among the thyroid/retinoid subgroup but is critical for the normal functioning of the VDR. In conclusion, we have identified a new mutation in the VDR gene that causes cellular hyporesponsiveness to $1,25(\mathrm{OH})_{2} \mathrm{D}_{3}$ that can be overcome by increasing concentrations of hormone.

\section{Acknowledgments}

We thank Drs. A. Bachy (Charleroi, Belgium) for referring the patient, J.W. Pike for the VDR antibody and phOC-CAT reporter plasmid, R. Evans for RXR $\alpha$ cDNA, C. Brenner for pG5, and K. Okuda for the 24-hydroxylase cDNA.

This work was supported by National Institutes of Health grant DK42482 (D. Feldman).

\section{References}

1. Feldman, D., and P.J. Malloy. 1990. Hereditary 1,25-dihydroxyvitamin D resistant rickets: molecular basis and implications for the role of $1,25(\mathrm{OH}) 2 \mathrm{D} 3$ in normal physiology. Mol. Cell. Endocrinol. 72:C57-62.

2. Hughes, M.R., P.J. Malloy, B.W. O'Malley, J.W. Pike, and D. Feldman. 1991. Genetic defects of the 1,25-dihydroxyvitamin D3 receptor. J. Recept. Res. 11:699-716.

3. Brooks, M.H., N.H. Bell, L. Love, P.H. Stern, E. Orfei, S.F. Queener, A.J. Hamstra, and H.F. DeLuca. 1978. Vitamin D-dependent rickets type II: resistance of target organs to 1,25-dihydroxyvitamin D. N. Engl. J. Med. 298:996999.

4. Rosen, J.F., A.R. Fleischman, L. Finberg, A. Hamstra, and H.F. Deluca. 1979. Rickets with alopecia: an inborn error of vitamin D metabolism. J. Pediatr. 94:729-735.

5. Beer, S., M. Tieder, D. Kohelet, O.A. Liberman, E. Vure, G. Bar-Joseph, D. Gabizon, Z.U. Borochowitz, W. Varon, and D. Modai. 1981. Vitamin D resistant rickets with alopecia: a form of end organ resistance to 1,25-dihydroxyvitamin D. Clin. Endocrinol. 14:395-402.

6. Feldman, D., T. Chen, C. Cone, M. Hirst, S. Shani, A. Benderli, and Z. Hochberg. 1982. Vitamin D resistant rickets with alopecia: cultured skin fibroblasts exhibit defective cytoplasmic receptors and unresponsiveness to 1,25(OH)2D3. J. Clin. Endocrinol. Metab. 55:1020-1022.

7. Clemens, T.L., J.S. Adams, N. Horiuchi, B.A. Gilchrest, H. Cho, Y Tsuchiya, N. Matsuo, T. Suda, and M.F. Holick. 1983. Interaction of 1,25-dihydroxyvitamin-D3 with keratinocytes and fibroblasts from skin of normal subjects and a subject with vitamin-D-dependent rickets, type II: a model for study of the mode of action of 1,25-dihydroxyvitamin D3. J. Clin. Endocrinol. Metab. 56:824-830.

8. Griffin, J.E., and J.E. Zerwekh. 1983. Impaired stimulation of 25-hydroxyvitamin D-24-hydroxylase in fibroblasts from a patient with vitamin D-dependent rickets, type II. A form of receptor positive resistance to 1,25-dihydroxyvitamin D3. J. Clin. Invest. 72:1190-1199.

9. Chen, T.L., M.A. Hirst, C.M. Cone, Z. Hochberg, H.-U. Tietze, and D. Feldman. 1984. 1,25-dihydroxyvitamin D resistance, rickets and alopecia: analysis of receptors and bioresponse in cultured fibroblasts from patients and parents. J. Clin. Endocrinol. Metab. 59:383-388.

10. Hochberg, Z., A. Benderli, J. Levy, P. Vardi, Y. Weisman, T. Chen, and D. Feldman. 1984. 1,25-dihydroxyvitamin D resistance, rickets and alopecia. Am. J. Med. 77:805-811. 
11. Gamblin, G.T., U.A. Liberman, C. Eil, R.W.J. Downs, D.A. Degrange, and S.J. Marx. 1985. Vitamin D dependent rickets type II: defective induction of 25-hydroxyvitamin D3-24-hydroxylase by 1,25-dihydroxyvitamin D3 in cultured skin fibroblasts. J. Clin. Invest. 75:954-960.

12. Hirst, M., H. Hochman, and D. Feldman. 1985. Vitamin D resistance and alopecia: a kindred with normal 1,25-dihydroxyvitamin D bindin, but decreased receptor affinity for deoxyribonucleic acid. J. Clin. Endocrinol. Metab. 60:490-495.

13. Hochberg, Z., A. Gilhar, S. Haim, R. Friedman-Birnbaum, J. Levy, and A. Benderly. 1985. Calcitriol-resistant rickets with alopecia. Arch. Dermatol. 121:646-647.

14. Liberman, U.A., C. Eil, and S.J. Marx. 1986. Receptor-positive hereditary resistance to 1,25-dihydroxyvitamin D: chromatography of receptor complexes on deoxyribonucleic acid-cellulose shows two classes of mutation. $J$. Clin. Endocrinol. Metab. 62:122-126.

15. Laufer, D., A. Benderly, and Z. Hochberg. 1987. Dental pathology in calcitirol resistant rickets. J. Oral Med. 42: 272-275.

16. Kikuchi, K., T. Okamoto, M. Nishino, E. Takeda, Y. Kuroda, and M. Miyao. 1988. Vitamin D-dependent rickets type II: report of three cases. ASDC J. Dent. Child. 55:465-468.

17. Malloy, P.J., Z. Hochberg, J.W. Pike, and D. Feldman. 1989. Abnormal binding of vitamin $\mathrm{D}$ receptors to deoxyribonucleic acid in a kindred with vitamin D-dependent rickets, type II. J. Clin. Endocrinol. Metab. 68:263-269.

18. Koeffler, H.P., J.E. Bishop, H. Reichel, F. Singer, A. Nagler, A. Tobler, M. Walka, and A.W. Norman. 1990. Lymphocyte cell lines from vitamin D-dependent rickets type II show functional defects in the $1 \alpha, 25$-dihydroxyvitamin D3 receptor. Mol. Cell. Endocrinol. 70:1-11.

19. Baker, A.R., D.P. McDonnell, M. Hughes, T.M. Crisp, D.J. Mangelsdorf, M.R. Haussler, J.W. Pike, J. Shine, and B.W. O'Malley. 1988. Cloning and expression of full-length cDNA encoding human vitamin D receptor. Proc. Natl. Acad. Sci. USA. 85:3294-3298.

20. Hughes, M.R., P.J. Malloy, D.G. Kieback, R.A. Kesterson, J.W. Pike, D. Feldman, and B.W. O'Malley. 1988. Point mutations in the human vitamin D receptor gene associated with hypocalcemic rickets. Science (Wash. DC). 242: $1702-1705$

21. Ritchie, H.H., M.R. Hughes, E.T. Thompson, P.J. Malloy, Z. Hochberg, D. Feldman, J.W. Pike, and B.W. O'Malley. 1989. An ochre mutation in the vitamin D receptor gene causes hereditary 1,25-dihdroxyvitamin D3-resistant rickets in three families. Proc. Natl. Acad. Sci. USA. 86:9783-9787.

22. Malloy, P.J., Z. Hochberg, D. Tiosano, J.W. Pike, M.R. Hughes, and D. Feldman. 1990. The molecular basis of hereditary 1,25-dihydroxyvitamin D3 resistant rickets in seven related families. J. Clin. Invest. 86:2071-2079.

23. Sone, T., S.J. Marx, U.A. Liberman, and J.W. Pike. 1990. A unique point mutation in the human vitamin D receptor chromosomal gene confers hereditary resistance to 1,25-dihydroxyvitamin D3. Mol. Endocrinol. 4:623-631.

24. Rut, A.R., M. Hewison, P. Rowe, M. Hughes, D. Grant, and J.L.H. O'Riordan. 1991. A novel mutation in the steroid binding region of the vitamin $\mathrm{D}$ receptor (VDR) gene in hereditary vitamin D resistant rickets (HVDRR). In Vitamin D: gene regulation, structure-function analysis, and clinical application. A.W. Norman, R. Bouillon, and M. Thomasset, editors. Walter de Gruyter, New York. 94-95.

25. Saijo, T., M. Ito, E. Takeda, A.H. Huq, E. Naito, I. Yokota, T. Sone, J.W. Pike, and Y. Kuroda. 1991. A unique mutation in the vitamin D receptor gene in three Japanese patients with vitamin D-dependent rickets type II: utility of single-strand conformation polymorphism analysis for heterozygous carrier detection. Am. J. Hum. Genet. 49:668-673.

26. Thompson, E., K. Kristjansson, and M. Hughes. 1991. Molecular scanning methods for mutation detection: application to the 1,25-dihydroxyvitamin D receptor. Eighth workshop on vitamin D. 8. (Abstr.). p. 6

27. Hewison, M., A.R. Rut, K. Kristjansson, R.E. Walker, M.J. Dillon, M.R. Hughes, and J.L. O'Riordan. 1993. Tissue resistance to 1,25-dihydroxyvitamin D without a mutation of the vitamin D receptor gene. Clin. Endocrinol. 39:663670 .

28. Kristjansson, K., A.R. Rut, M. Hewison, J.L. O'Riordan, and M.R. Hughes. 1993. Two mutations in the hormone binding domain of the vitamin D receptor cause tissue resistance to 1,25 dihydroxyvitamin D3. J. Clin. Invest. 92 : $12-16$

29. Yagi, H., K. Ozono, H. Miyake, K. Nagashima, T. Kuroume, and J.W. Pike. 1993. A new point mutation in the deoxyribonucleic acid-binding domain of the vitamin D receptor in a kindred with hereditary 1,25-dihydroxyvitamin D-resistant rickets. J. Clin. Endocrinol. Metab. 76:509-512.

30. Wiese, R.J., H. Goto, J.M. Prahl, S.J. Marx, M. Thomas, A. al-Aqeel, and H.F. DeLuca. 1993. Vitamin D-dependency rickets type II: truncated vitamin D receptor in three kindreds. Mol. Cell. Endocrinol. 90:197-201.

31. Malloy, P.J., Y. Weisman, and D. Feldman. 1994. Hereditary $1 \alpha, 25-$ dihydroxyvitamin D-resistant rickets resulting from a mutation in the vitamin D receptor deoxyribonucleic acid-binding domain. J. Clin. Endocrinol. Metab. 78:313-316.

32. Lin, N.U.-T., P.J. Malloy, N. Sakati, A. Al-Ashwal, and D. Feldman. 1996. A novel mutation in the deoxyribonucleic acid-binding domain of the vitamin D receptor gene causes hereditary 1,25-dihydroxyvitamin D resistant rickets. J. Clin. Endocrinol. Metab. 81:2564-2569.

33. Evans, R.M. 1988. The steroid and thyroid hormone receptor superfamily. Science (Wash. DC). 240:889-895.

34. Mangelsdorf, D.J., and R.M. Evans. 1995. The RXR heterodimers and orphan receptors. Cell. 83:841-850.

35. Forman, B.M., and H.H. Samuels. 1990. Interactions among a subfamily of nuclear hormone receptors: the regulatory zipper model. Mol. Endocrinol. 4: 1293-1301.

36. Sone, T., R.A., Scott, M.R. Hughes, P.J. Malloy, D. Feldman, B.W O'Malley, and J.W. Pike. 1989. Mutant vitamin D receptors which confer hereditary resistance to 1,25 -dihydroxyvitamin D3 in humans are transcriptionally inactive in vitro. J. Biol. Chem. 264:20230-20234.

37. Van Maldergem, L., A. Bachy, D. Feldman, R. Bouillon, J. Maassen, M. Dreyer, R. Rey, C. Holm, and Y. Gillerot. 1996. Syndrome of lipoatrophic diabetes, vitamin $\mathrm{D}$ resistant rickets, and persistent müllerian ducts in a Turkish boy born to consanguineous parents. Am. J. Med. Genet. 64:506-513.

38. Bradford, M.M. 1976. A rapid and sensitive method for the quantitation of microgram quantities of protein utilizing the principle of protein dye binding. Anal. Biochem. 72:248-254.

39. Skowronski, R.J., D.M. Peehl, and D. Feldman. 1993. Vitamin D and prostate cancer: 1,25 Dihydroxyvitamin D3 receptors and actions in human prostate cancer cell lines. Endocrinology. 132:1952-1960.

40. Malloy, P.J., X. Zhao, N.D. Madani, and D. Feldman. 1993. Cloning and expression of the gene from Candida albicans that encodes a high-affinity corticosteroid-binding protein. Proc. Natl. Acad. Sci. USA. 90:1902-1906.

41. Hijiya, N., M. Setoguchi, K. Matsuura, Y. Higuchi, S. Akizuki, and S. Yamamato. 1994. Cloning and characterization of the human osteopontin gene and its promoter. Biochem J. 303:255-262.

42. Ohyama, Y., M. Noshiro, and K. Okuda. 1991. Cloning and expression of cDNA encoding 25-hydroxyvitamin D3 24-hydroxylase. FEBS Lett. 278:195198.

43. Marx, S.J., M.M. Bliziotes, and M. Nanes. 1986. Analysis of the relation between alopecia and resistance to 1,25-dihydroxyvitamin D. Clin. Endocrinol. 25:373-381.

44. Takeda, E., Y. Kuroda, T. Saijo, E. Naito, H. Kobashi, I. Yokota, and M. Miyao. 1987. 1 alpha-hydroxyvitamin D3 treatment of three patients with 1,25-dihydroxyvitamin D-receptor-defect rickets and alopecia. Pediatrics. 80: 97-101.

45. Takeda, E., I. Yokota, I. Kawakami, T. Hashimoto, Y. Kuroda, and S Arase. 1989. Two siblings with vitamin-D-dependent rickets type II: no recurrence of rickets for 14 years after cessation of therapy. Eur. J. Pediatr. 149:5457.

46. al-Aqeel, A., P. Ozand, S. Sobki, W. Sewairi, and S. Marx. 1993. The combined use of intravenous and oral calcium for the treatment of vitamin D dependent rickets type II (VDDRII). Clin. Endocrinol. 39:229-237.

47. Balsan, S., M. Garabedian, M. Larchet, A.M. Gorski, G. Cournot, C. Tau, A. Bourdeau, C. Silve, and C. Ricour. 1986. Long-term nocturnal calcium infusions can cure rickets and promote normal mineralization in hereditary resistance to 1,25-dihydroxyvitamin D. J. Clin. Invest. 77:1661-1667.

48. Weisman, Y., I. Bab, D. Gazit, Z. Spirer, M. Jaffe, and Z. Hochberg. 1987. Long-term intracaval calcium infusion therapy in end-organ resistance to 1,25-dihydroxyvitamin D. Am. J. Med. 83:984-990.

49. Bliziotes, M., A.L. Yergey, M.S. Nanes, J. Meunzer, M.G. Begley, N.E. Viera, K.K. Kher, M.L. Brandi, and S.J. Marx. 1988. Absent intestinal response to calciferols in hereditary resistance to 1,25-dihydroxyvitamin D: documentation and effective therapy with high dose intravenous calcium infusions. J. Clin Endocrinol. Metab. 66:294-300.

50. Wagner, R.L., J.W. Apriletti, M.E. McGrath, B.L. West, J.D. Baxter, and R.J. Fletterick. 1995. A structural role for hormone in the thyroid hormone receptor. Nature (Lond.). 378:690-697.

51. Renaud, J.P., N. Rochel, M. Ruff, V. Vivat, P. Chambon, H. Gronemeyer, and D. Moras. 1995. Crystal structure of the RAR-gamma ligand-binding domain bound to all-trans retinoic acid. Nature (Lond.). 378:681-689.

52. Bourguet, W., M. Ruff, P. Chambon, H. Gronemeyer, and D. Moras. 1995. Crystal structure of the ligand-binding domain of the human nuclear receptor RXR-alpha. Nature (Lond.). 375:377-382.

53. Refetoff, S., R.E. Weiss, and S.J. Usala. 1993. The syndromes of resistance to thyroid hormone. Endocrinol. Rev. 14:348-399. 